\title{
PENYULUHAN PEMANFAATAN TANAMAN OBAT KELUARGA DAN PENANAMAN TANAMAN OBAT KELUARGA DI PERUMAHAN BERINGIN RINDANG KABUPATEN KOTAWARINGIN BARAT
}

\author{
Poppy Dwi Citra Jaluri ${ }^{1}$ Mustika Antik Wibawa ${ }^{2}$ Rahman Nur Chabib ${ }^{3}$ \\ ${ }^{123}$ STIKEs Borneo Cendekia Medika Pangkalan Bun \\ ${ }^{1}$ Email : Poppyjaluri@gmail.com
}

\begin{abstract}
ABSTRAK
Kegiatan menanami pekarangan dengan tananam obat dikenal dengan nama toga. Program yang dahulu dinamai apoetik hidup ini tengah digunakan oleh pemerintah indonesia. Istilah toga lebih mengacu kepada penataan pekarangan. Jadi tidak berarti tanaman yang hanya tanaman hias yang berkhasiat obat. Tanaman obat yang tergolong rempah-rempah atau bumbu dapur, tananam pagar, tanaman buah, tanaman sayur, atau bahkan tananam liar pun dapat ditata di pekarangan sebagai toga. Selain sebagai bahan obat bagi anggota keluarga yang sakit, tanaman tersebut dapat dimanfaatkan untuk aneka keperluan sesuai dengan kegunaan lainnya. Metode yang digunakan dalam kegiatan pengabdian masyarakat ini yaitu diawali dengan pretest, kemudian penyuluhan materi dan terakhir postest. Dari pelaksanaan pengabdian kepada masyarakat berupa penyuluhan ini dapat dilihat bahwa sebagian besar peserta penyuluhan yaitu 28 orang dari 35 orang $(80 \%)$ belum pernah mendapatkan penyuluhan mengenai TOGA, semua peserta penyuluhan 35 orang (100\%) belum mengetahui sembilan tanaman obat yang sudah mengalami uji klinik, hanya sebagian kecil dari peserta yaitu 7 orang dari 35 orang (20\%) yang sudah menanam TOGA di rumah atau lingkungannya, dan hanya sebagian kecil dari peserta yaitu 7 orang dari 35 orang $(20 \%)$ yang sudah pernah memanfaatkan TOGA.
\end{abstract}

Kata kunci : toga, lingkungan, masyarakat

\section{COUNSELING THE USE OF FAMILY MEDICINE PLANT AND PLANT FAMILY MEDICINE PLANTING IN BANYAN HOUSING SHADY DISTRICT KOTAWARWANT WEST}

\begin{abstract}
The activity of planting yard with drug tank is known as toga. The Program that was once named this Life pharmacy is used by the Government of Indonesia. The term toga is more referring to the arrangement of the yard. So it does not mean plants that are only ornamental plants that efficacious medicinal. Medicinal plants that belong to the spice or spice kitchen, bunch of fences, fruit crops, vegetable plants, or even wild soil can be styled in the yard as toga. In addition to being a medicinal ingredient for sick family members, the plant can be used for various purposes according to other uses. The method used in community service activities is preceded by pretest, then the material extension and the last postest. From the implementation of devotion to the community in the form of counseling can be seen that most of the
\end{abstract}


counseling participants are 28 people from 35 people (80\%) Never get counseling about TOGA, all counseling participants 35 people (100\%) Not know nine medicinal plants that have undergone clinical trials, only a small part of the participants are 7 people from 35 people (20\%) That has planted TOGA in the house or its environment, and only a small part of the participants were 7 people from 35 people (20\%) who have used TOGA.

Keywords: toga, environment, society

\section{PENDAHULUAN}

Kegiatan menanami pekarangan dengan tananam obat dikenal dengan nama toga. Program yang dahulu dinamai apoetik hidup ini tengah digunakan oleh pemerintah indonesia. Istilah toga lebih mengacu kepada penataan pekarangan. Jadi tidak berarti tanaman yang hanya tanaman hias yang berkhasiat obat. Tanaman obat yang tergolong rempah-rempah atau bumbu dapur, tananam pagar, tanaman buah, tanaman sayur, atau bahkan tananam liar pun dapat ditata di pekarangan sebagai toga. Selain sebagai bahan obat bagi anggota keluarga yang sakit, tanaman tersebut dapat dimanfaatkan untuk aneka keperluan sesuai dengan kegunaan lainnya. (Agus Hikmah,2011).

Tanaman Obat Keluarga (TOGA) adalah tanaman hasil budi daya rumahan yang berkhasiat sebagai obat, dimanfaatkan dalam upaya peningkatan kesehatan baik dalam upaya preventif, promotif maupun kuratif. Bagian dari tumbuhan yang dapat dimanfaatkan sebagai obat adalah bagian daun, kulit batang, buah, biji dan akarnya. Umumnya TOGA dimanfaatkan sebagai minuman kebugaran, ramuan untuk gangguan kesehatan ringan berdasarkan gejala, ramuan khusus untuk lansia, memelihara kesehatan ibu, meningkatkan gizi anak. (Agus Hikmah,2011)
Pekarangan biasanya memiliki luas lahan terbatas, maka jenis tanaman obat sebaiknya dipilih yang penting dan bermanfaat untuk keperluan menjaga kesehatan keluarga sehari hari. Selain itu, dipilih jenis tanaman yang mudah dibudidayakan dan tidak menyita tempat karena ukuran tajuk yang besar. Karena sifat pekarangan berbeda dengan kebun atau ladang, maka pemilihan tanaman juga harus memperhatikan factor keindahan serta memperhatkan kondisi halaman, misalnya, kontur tanah, bentuk serta adanya pohon atau bangunan lain.Faktor paling penting dalam mengatur lahan untuk tanaman obat adalah memperhatikan estetika (keindahan).Jangan sampai tanaman obat yang kita tanam di halaman merusak/mengganggu pemandangan. Juga harus diperhatikan keberadaan elemen taman lain, yaitu soft material misalnya kandang ternak,tiang bendera, jalan tapak kolam ikan dan lain - lain. (Made Deviani Duaja dkk, 2011).

Dewasa ini obat-obata modern sudah menjadi bagian dari kehidupan kita sehari-hari. Obat-obatan itu dalam berbagai bentuk sudah dijual bebas dan mudah sekali didapatkan dengan harga yang relatif terjangkau seluruh lapisan masyarakat. Akhir-akhir ini trend pengobatan modern cenderung kembali ke tanaman obat yang digunakan secara tradisional.Ada beberapa alasan yang mendasari kecendrungan ini. Misalnya,tanaman obat yang digunakan 
secara tepat, tidak atau kurang menimbulkan efek samping dibandingkan dengan obat-obatan modern terutaman yang dibuat dari bahan sintesis. Alasan lain, obat-obatan tradisional juga lebih tepat untuk digunakan sebagai penyakit atau untuk menjaga kesehatan. (Yanti Harjono dkk, 2017).

Tanaman obat merupakan salah satu sumber daya yang sudah ada sejak dahulu kala dimanfaatkan oleh nenek moyang kita dalam upaya mengatasi masalah kesehatan dengan menjadikan berbagai ramuan bahan tanaman obat. Oleh karena itu pemanfaatan tanaman obat keluarga (TOGA) perlu dikembangkan dan disebar luaskan di masyarakat terutama untuk ibu-ibu rumah tangga. Ibu rumah tangga sangat berperan dalam masalah kesehatan, sehingga apabila anggota keluarga ada yang sakit maka ibu rumah tanggalah yang melakukan pencegahan pertama dalam mengatasi masalah kesehatan. Namun dewasa ini banyak kecenderungan perubahan sikap konsumen dalam masalah mengkonsumsi obatobatan untuk kesehatan. Kesehatan bagi kelangsungan hidup kita sangat penting sekali, karena tanpa kesehatan kita tidak dapat melakukan berbagai aktivitas yang dapat mempertahankan hidup di dunia ini. (Yanti Harjono dkk, 2017).

\section{METODE PENELITIAN}

1. Masyarakat khususnya ibu rumah tangga perumahan beringin rindang kabupaten kotawaringin barat dikumpulkan di suatu tempat yang memiliki kapasitas yang cukup banyak

2. Dilakukan pretest berupa tanya jawab untuk mengetahui tingkat pengetahuan masyarakat mengenai tanaman obat keluarga

3. Dilakukan pemaparan materi mengenai 9 tanaman obat keluarga yang telah lulus uji klinis serta pemanfaatannya bagi kesehatan keluarga

4. Dilakukan evaluasi berupa postest tanya jawab untuk mengetahui sejauh mana masyarakat khususnya ibu rumah tangga mengetahui 9 tanaman obat keluarga yang telah lulus uji klinis

5. Mengenalkan cara pembudidayaan TOGA dengan mendemonstrasikan cara penanaman bersama di suatu halaman rumah masyarakat.

\section{HASIL PENELITIAN}

1. Sebagian besar peserta penyuluhan $(80 \%)$ belum pernah mendapatkan penyuluhan mengenai TOGA

2. Semua peserta penyuluhan $(100 \%)$ belum mengetahui sembilan tanaman obat yang sudah mengalami uji klinik

3. Hanya sebagian kecil dari peserta (20\%) yang sudah menanam TOGA di rumah atau lingkungannya, dan hanya sebagian kecil dari peserta $(20 \%)$ yang sudah pernah memanfaatkan TOGA

\section{PEMBAHASAN}

Kegiatan pengabdian kepada masyarakat berupa penyuluhan tanaman obat keluarga bertujuan untuk meningkatkan pengetahuan, pemanfaatan dan keterampilan menanam tanaman yang termasuk sembilan jenis tanaman obat unggulan, diharapkan dengan meningkatnya pengetahuan mengenai TOGA dapat meningkatkan derajat kesehatan masyarakat yang berada di wilayah 
perumahan beringin rindang kabupaten kotawaringin barat.

Dari pelaksanaan pengabdian kepada masyarakat berupa penyuluhan ini dapat dilihat bahwa sebagian besar peserta penyuluhan yaitu 28 orang dari 35 orang $(80 \%)$ belum pernah mendapatkan penyuluhan mengenai TOGA, semua peserta penyuluhan 35 orang (100\%) belum mengetahui sembilan tanaman obat yang sudah mengalami uji klinik, hanya sebagian kecil dari peserta yaitu 7 orang dari 35 orang (20\%) yang sudah menanam TOGA di rumah atau lingkungannya, dan hanya sebagian kecil dari peserta yaitu 7 orang dari 35 orang (20\%) yang sudah pernah memanfaatkan TOGA.

Keberhasilan pelaksanaan pengabdian kepada masyarakat ini dapat dilihat dari ketercapaian target jumlah peserta, ketercapaian tujuan dan ketercapaian target materi. Ketercapaian tujuan dapat dikatakan baik, dari hasil pretest dan posttest terdapat peningkatan pengetahuan dari ibu-ibu peserta penyuluhan. Ketercapaian target materi dapat dikatakan baik $(80 \%)$ dilihat dari semua materi pelatihan dapat disampaikan oleh tim pengabdian kepada masyarakat dengan waktu yang terbatas dan dari keberhasilan penanaman TOGA di rumah yaitu $80 \%$.

\section{KESIMPULAN DAN SARAN}

\section{Kesimpulan}

Dapat disimpulkan bahwa penyuluhan dan sosialisasi mengenai TOGA dan TOGA yang sudah mengalami uji klinik meningkatkan pengetahuan dan pemahaman masyarakat tentang TOGA dan TOGA yang sudah dapat dipertanggungjawabkan pemakaiannya secara ilmiah.

\section{Saran}

Berdasarkan hasil yang dicapai, disarankan untuk melakukan penyuluhan dan sosialisasi TOGA yang sudah melalui uji klinik di wilayah lainnya dan meningkatkan pemanfaatannya untuk peningkatan kesehatan dan pencegahan penyakit.

\section{DAFTAR PUSTAKA}

Duaja, Made Deviani. Kartika, Elis. Mukhlis, Fuad. 2011. Peningkatan Kesehatan Mayarakat Melalui

Pemberdayaan Wanita dalam Pemanfaatan Pekarangan dengan Tanaman Obat Keluarga (TOGA) di Kecamatan Geragai. Fakultas Pertanian Universitas Jambi. Jurnal Pengabdian Masyarakat No.52.

Sidik, Rahmat Fajar. 2014. Pembelajaran Ilmu Pengetahuan Alam Temetik Berbasis Tanaman Obat Keluarga (TOGA). Universitas Trunojoyo Madura. Jurnal Pena Sains Vol.1, No. 1.

Mindarti, Susi. Nurbaeti, Bebet. 2015. Buku Saku Tanaman Obat Keluarga. Balai Pengkajian Teknologi Pertanian (BPTP) Jawa Barat.

Hikmah, Agus. Zuhud, Ervizal A.M. Siswoyo. Dkk. 2011. Revitalisasi Konservasi Tumbuhan Obat Keluarga (TOGA) Guna Meningkatkan Kesehatan dan Ekonomi Keluarga Mandari di Desa Contoh Lingkar Kampus IPB Darmaga Bogor. Kampus IPB 
Darmaga Bogor. Jurnal Ilmu Pertanian Indonesia. Hlm.7180.

Harjono, Yanti. Yusmaini, Hany. Bahar, Meiskha.2017.

Penyuluhan Pemanfaatan

Tanaman Obat Keluarga dan Penanaman Tanaman Obat Keluarga di Kampung Mekar Bakti 01/01, Desa Mekar Bakti Kabupaten Tanggerang. FK UPN Veteran Jakarta.

Febriansyah, $\quad$ Rifki. 2017. Pemberdayaan Kelompok Tanaman Obat Keluarga Menuju Keluarga Sehat Didesa Sumber Adi, Mlati, Sleman. Universitas Muhammadiyah Yogyakarta. Jurnal Bardikari Vol. 5 No.2.

Rahmatini, 2010. Evaluasi Khasiat dan Keamanan Obat (Uji Klinik). Fakultas Kedokteran Universitas Andalas. Majalah Kedokteran Andalas No.1 Vol.34. 